\title{
Improvement in Sensory Properties of Micro-Polluted Lake Water Using Membrane Reactor Combined Process
}

\author{
Changshuang Zhao ${ }^{1}$, Xiaoping Xu ${ }^{1 *}$, Renjun Ruan ${ }^{1}$, Xueyu Wei ${ }^{1}$, \\ Jiashun $\mathrm{Cao}^{2}$, Qiang $\mathrm{Liu}^{3}$ \\ ${ }^{1}$ College of Civil Engineering and Architecture, Anhui Polytechnic University, 241000, Wuhu, China \\ ${ }^{2}$ College of Environment, Hohai University, Nanjing, 210098, China \\ ${ }^{3}$ School of Environmental Engineering, Xuzhou Institute of Technology, Xuzhou 221018, China
}

Received: 8 April 2021

Accepted: 2 September 2021

\begin{abstract}
To improve the water quality of micro-polluted lake water, an integrated process of dissolved air flotation (DAF)/modified attapulgite (M-ATP)/membrane filtration was applied to treat micro-polluted lake water with poor sensory attributes. The results showed that the average removal rate for water turbidity, color and odor using this process system were $95.8 \%, 83.1 \%$, and $90.0 \%$ in order. Moreover, the M-ATP unit had the best treatment effect in turbidity and odor removal, with removal rates of $48.7 \%$ and $49.8 \%$, respectively. While the DAF unit could remove $46.6 \%$ of the color at the same time. Based on the analysis of different processing units, the correlation between the removal rates of different processing units was explored using SPSS software. The results indicated that correlation between the three processing units is negative. In addition, in the three-month operation period, the initial transmembrane pressure (TMP) of the membrane device was about $2.3 \mathrm{kPa}$, and the final TMP was only about $4.5 \mathrm{kPa}$. This research provided technical reference for the treatment of micro-polluted lake water.
\end{abstract}

Keywords: dissolved air flotation, modified attapulgite, membrane filtration, micro-polluted lake water, sensory attributes

\section{Introduction}

The pollution of water resources not only severely damages the ecology, but also directly endangers human health. After water resources are contaminated, the pollutants enter the human body through drinking water or the food chain, causing acute or

e-mail: xuxp1979@126.com chronic poisoning, and can also induce cancer [1-2]. Agricultural and industrial wastewater pollutes water sources and can cause harm to multiple organs of the human body. Water contaminated by parasites, viruses or other pathogenic bacteria can cause a variety of infectious diseases and parasitic diseases [3]. In recent years, the rapid development of economy, technology and urban population have led to the rapid increase of agricultural, industrial and domestic wastewater discharge. As a result, the pollution load of lakes in 
the city is increasing, and the water environment of the lakes continues to deteriorate [4].

According to Ecological Environment Bulletin of China in 2019, in the 1913 surface water quality monitoring sections and 110 important lakes (reservoir) water quality monitoring sections across the country, the proportions of water quality of Grade IV and above are $25.1 \%$ and $30.9 \%$, respectively [5]. This shows that the situation of lake water environment is still not optimistic. In addition to the conventional water pollution indicators, people are concerned about some sensory indicators of water bodies, such as turbidity, color, and odor, which affects the sensory evaluation of urban water environment and the quality of drinking water for urban residents [6-8].

Because of poor coagulation effect and organic matter removal rate, as well as high odor concentration in the effluent [9-11], it is difficult for conventional water purification processes to meet the increasingly stringent water quality standards when treating surface water with low turbidity, high organic concentration, and high nutrient concentrate [12-13]. Moreover, the disinfection by-products are harmful to organism [14]. Therefore, the development of a low-consumption and high-efficiency surface water treatment process is of great significance for improving the surface water environment, the safety and reliability of high drinking water.

DAF is a water treatment technology that uses micro-bubbles to adsorb suspended solids and then rise to the water surface [15]. It is currently widely used in sewage treatment, surface water purification and industrial wastewater treatment industries. Relevant studies have shown that the DAF process has a good removal effect on algae, which is an important source of odor [16]. At the same time, the adsorption capacity of natural attapulgite is greatly improved after modified treatment, and the membrane bioreactor has the advantages of good effluent sensory properties [17-19].

In view of the sensory properties of micro-polluted lake water, combined with the above three process, the DAF/M-ATP/membrane integrated process was developed [20]. The combined system was used to treat the micro-polluted lake water, and its treatment efficiency on sensory properties index were studied. Compared with traditional tap water treatment process of coagulation, precipitation, filtration and disinfection, with the rapid cost decrease of membrane treatment materials, this combined process can reduce the treatment cost to a certain extent. At the same time, membrane filtration, as the final processing unit, can reliably guarantee the effluent quality when the water quality fluctuates during the previous treatment process.

The aim of this study is to explore the efficiency of DAF/ M-ATP/membrane combined process on micropolluted lake water. This investigation will further explore the microbial community changes in the M-ATP and further optimize the membrane fouling problem.

\section{Materials and Methods}

\section{Experimental Set-Up}

The integrated system is mainly composed of DAF process unit, M-ATP filter unit and membrane filtration unit (Fig. 1). The effective volume of the device is about 500L. First, the raw water enters the mixing chamber after dosing and flocculation, and is mixed with the microbubbles generated by the pressurized dissolved air flotation method. Then the generated scum is scraped off by a slag scraper. The DAF effluent water enters the M-ATP filter unit, flows down through the filter and finally enters the membrane processing unit. In the end, membrane effluent is discharged into the outlet tank through the drainage pipe after being filtered by the membrane. This combined device has been continuously optimized in previous research, and it could keep high operating efficiency steady.

Natural attapulgite were taken from Xuyi County of Jiangsu Province, and treated with sulfuric acidultrasonic modification method to prepare M-ATP particles with a particle size of 20-60 mesh [21]. The main physical indicators of M-ATP particles are shown in Table 1.

In view of the lake water quality characteristics and the materials economic applicability, polyvinylidene fluoride flat microfiltration membrane were selected as the experimental membrane with a pore size of $0.2 \mu \mathrm{m}$ and an effective area of $0.05 \mathrm{~m}^{2}$ (Bona, America).

\section{Source Water}

The raw water was sampled from Gehu lake (11944'15"E 11952'56"E, 3142'04"N 3128'19"N) in Changzhou of Jiangsu Province, China. During the experiment, turbidity, color and odor of raw water were approximately 7.0-8.3 NTU, 30-40 and 55-65 respectively. Water temperature and $\mathrm{pH}$ were measured by the lake, and other water quality indicators were transported back to the laboratory for further determination.

Table 1. Contrast table of attapulgite physical properties before and after modification

\begin{tabular}{|c|c|c|c|}
\hline Sample & Specific surface area $\left(\mathrm{m}^{2} / \mathrm{g}\right)$ & Average pore diameter $(\mathrm{nm})$ & Pore volume $\left(\mathrm{cm}^{3} / \mathrm{g}\right)$ \\
\hline Natural ATP & 2.034 & 10.5345 & 0.1203 \\
\hline Modified ATP & 93.369 & 8.7043 & 0.2095 \\
\hline
\end{tabular}




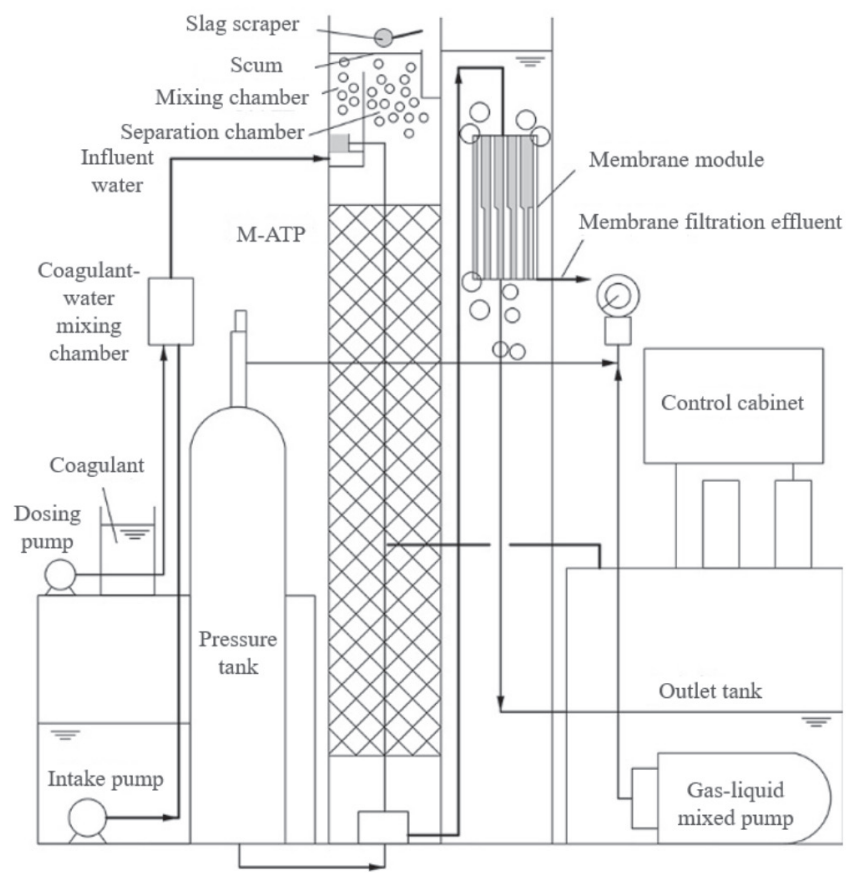

Fig. 1. Configuration of DAF/M-ATP/membrane integrated system.

\section{Operation Protocol}

The system started running on June 10, and lasted for more than 90 days. During the xperiment, the main operating parameters were listed in Table 3. The pause period of the membrane device was set at $5 \mathrm{~min} / \mathrm{h}$, and during the pause, the membrane surface were aerated and cleaned by aeration device. Samples were taken from outlet tank every 1 day (1-10d), 2 days (10-30d), 3 days (30-60d) and 4 days (60-90d). The measurement immediately started after the water sample was taken.

\section{Analytical Methods}

\section{Conventional Indicators Analysis}

PAC (Polyaluminum chloride, CAS:1327-41-9, $\mathrm{AlClHO}$, purity $>99.5 \%$ ) were purchased from Sinopharm Chemical Reagent Co., Ltd. (Shanghai, China) and dissolved to prepare $4 \mathrm{mg} / \mathrm{L}$ solutions before use. Promazine hydrochloride (CAS: 53-60-1, C17H21ClN2S, purity $>99 \%$ ) were purchased from Beijing Sunkeda Technology Co., Ltd. (Beijing, China) and then were stored at $4^{\circ} \mathrm{C}$.

Turbidity was measured by Turb550 digital turbidity meter (WYW, Germany); color was measured by platinum-cobalt standard colorimetry [22]; odor was measured by odor threshold method [23]; transmembrane pressure difference was measured by vacuum gauge; water temperature was measured by cnjw/JW01 type thermometer (WELLDAY, China); pH was determined by HQ40d portable $\mathrm{pH}$ meter (Hach, America).

\section{Characterization of $M-A T P$}

The modification method reference [24]. The surface properties of prepared modified attapulgite, including specific surface area and pore size analysis, and surface morphology, were measured by surface area porosity analyzer (BET, Beishide PS1) and scanning electron microscopy (SEM, JEOL JSMIT800) respectively.

\section{Statistical Analysis}

All figures were carried out using the ORIGIN package 8.5 (ORIGIN Inc.). Correlation coefficient of removal rate were carried out by SPSS package 17.0 (SPSS Inc.). The correlation coefficient was conducted by Pearson Correlation Coefficient, followed the significance test was a two-tailed test.

Table 2. Main process parameters.

\begin{tabular}{|c|c|c|c|c|c|c|c|c|}
\hline $\begin{array}{c}\text { Water } \\
\text { inflow }\end{array}$ & $\begin{array}{c}\text { Flocculating } \\
\text { time }\end{array}$ & $\begin{array}{c}\text { HRT of mixing } \\
\text { chamber }\end{array}$ & $\begin{array}{c}\text { Reflux } \\
\text { ratio }\end{array}$ & $\begin{array}{c}\text { HRT of separation } \\
\text { chambe }\end{array}$ & $\begin{array}{c}\text { Thickness } \\
\text { of M-ATP }\end{array}$ & $\begin{array}{c}\text { Filtering } \\
\text { velocity }\end{array}$ & $\begin{array}{c}\text { Membrane } \\
\text { pore size }\end{array}$ & $\begin{array}{c}\text { Designed } \\
\text { membrane flux }\end{array}$ \\
\hline $2 \mathrm{~L} / \mathrm{h}$ & $15 \mathrm{~min}$ & $8 \mathrm{~min}$ & $15 \%$ & $20 \mathrm{~min}$ & $800 \mathrm{~mm}$ & $1 \mathrm{~m} / \mathrm{h}$ & $0.2 \mu \mathrm{m}$ & $30 \mathrm{~L} /\left(\mathrm{m}^{2} \cdot \mathrm{h}\right)$ \\
\hline
\end{tabular}


Table 3. Correlation coefficient of removal rate.

\begin{tabular}{|c|c|c|c|c|c|c|c|c|c|c|}
\hline \multirow{2}{*}{$\begin{array}{l}\text { Removal } \\
\text { rate }\end{array}$} & \multirow[b]{2}{*}{ Parameter } & \multicolumn{3}{|c|}{ Turbidity } & \multicolumn{3}{|c|}{ Color } & \multicolumn{3}{|c|}{ Odor } \\
\hline & & DAF & M-ATP & $\begin{array}{l}\text { Mem- } \\
\text { brane }\end{array}$ & DAF & M-ATP & $\begin{array}{l}\text { Mem- } \\
\text { brane }\end{array}$ & DAF & M-ATP & $\begin{array}{l}\text { Mem- } \\
\text { brane }\end{array}$ \\
\hline \multirow[t]{2}{*}{ DAF } & $\begin{array}{l}\text { Pearson Correlation } \\
\text { Coefficient }\end{array}$ & 1 & & & 1 & & & 1 & & \\
\hline & Sig0.( two-tail) & & & & & & & & & \\
\hline \multirow[t]{2}{*}{ M-ATP } & $\begin{array}{l}\text { Pearson Correlation } \\
\text { Coefficient }\end{array}$ & $-0.583 * *$ & 1 & & $-0.532 * *$ & 1 & & $-0.473 * *$ & 1 & \\
\hline & Sig0.( two-tail) & 0.000 & & & 0.001 & & & 0.003 & & \\
\hline \multirow{2}{*}{$\begin{array}{l}\text { Mem- } \\
\text { brane }\end{array}$} & $\begin{array}{l}\text { Pearson Correlation } \\
\text { Coefficient }\end{array}$ & $-0.658 * *$ & -0.137 & 1 & $-0.621 * *$ & -0.170 & 1 & $-0.373^{*}$ & $-0.536^{* *}$ & 1 \\
\hline & Sig0.( two-tail) & 0.000 & 0.417 & & 0.000 & 0.314 & & 0.023 & 0.001 & \\
\hline
\end{tabular}

Note: When the correlation coefficient $r=1$, it is a completely positive correlation, and when $r=-1$, it is a completely negative correlation. The closer $|r|$ is to 1 , the closer the correlation is. ${ }^{* *}$ Indicates that the correlation is significant at the 0.01 level (two-tailed).

\section{Results and Discussion}

Results

\section{Turbidity Removal in Three Units}

The variations in water turbidity after each processing unit were shown in Figs 2 and 3. the average turbidity of raw water was around $7.48 \pm$ NTU during the experiment. And final turbidity of effluent was $0.32 \pm$ NTU. Overall, the average turbidity removal rate was $95.8 \%$ using this integrated processing system (Fig. 2b). For the DAF processing unit, the raw water was coagulated, and then the turbidity of effluent maintained between 4.71 NTU and 5.59 NTU, meaning the average removal rate was $30.7 \%$. The turbidity of M-ATP effluent was between 1.18 NTU and $1.85 \mathrm{NTU}$ with an average value of $1.53 \mathrm{NTU}$. This unit contributed about $48.7 \%$ to turbidity removal. The turbidity of membrane effluent was around $0.10 \sim 0.60 \mathrm{NTU}$ with an average value of $0.32 \pm \mathrm{NTU}$. The average removal rate in this processing unit was $16.4 \%$. In the later stage of the experiment, the turbidity of membrane effluent was basically between $0.10 \sim 0.20 \mathrm{NTU}$. In summary, the order of turbidity removal rate of the above three treatment units was M-ATP $>$ DAF $>$ membrane.

\section{Color Removal in Three Units}

As shown in Figs 4 and 5, the average raw water color were 33.51 while the membrane effluent color was 5.68, and the average color removal rate was $83.1 \%$. After the raw water was coagulated, the color of DAF effluent water was between 15 and 25 , which the average value was 17.70 , and the average removal rate was $46.6 \%$. The color of M-ATP effluent was between $10 \sim 15$, which the average value was 13.11 , and the average removal rate is $13.9 \%$. The color of membrane effluent was between 5 10, which the average value was 5.68 , and the average removal rate was $22.6 \%$.

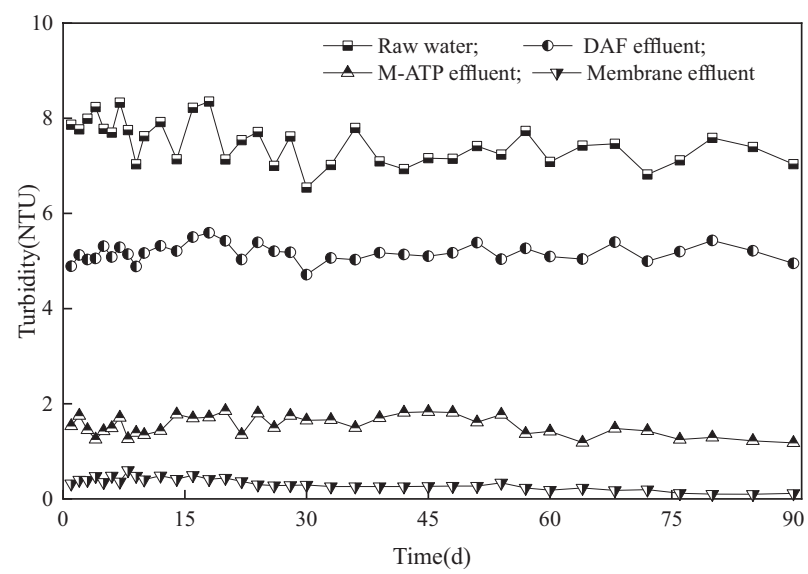

Fig. 2. Turbidity removal by the integrated process.

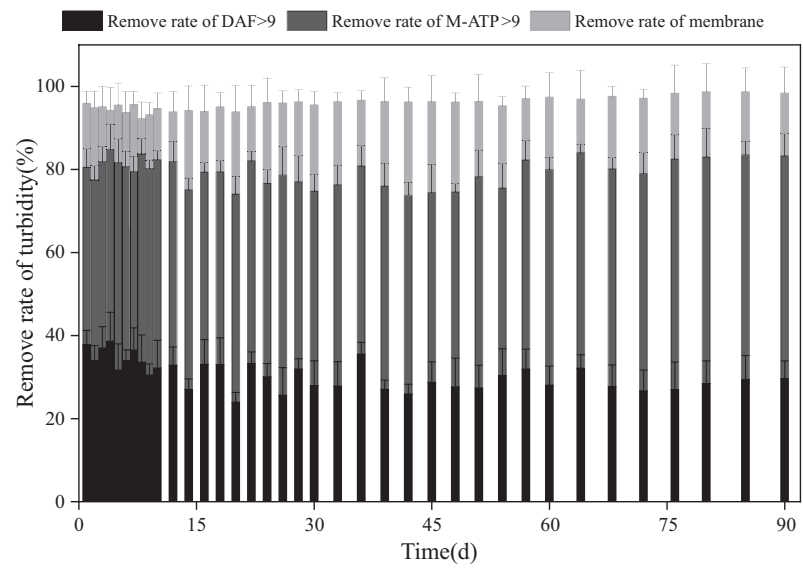

Fig. 3. Comparison of turbidity removal rate of different processing units. 


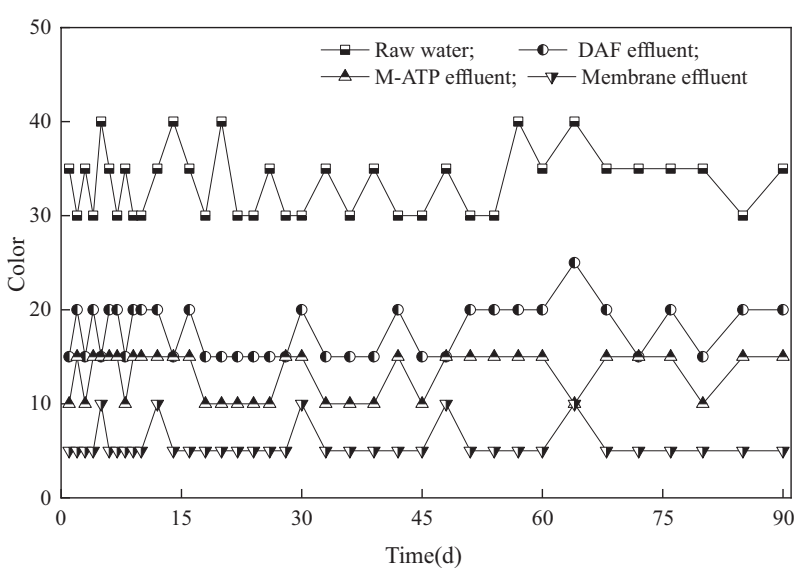

Fig. 4. Color removal by the integrated process.

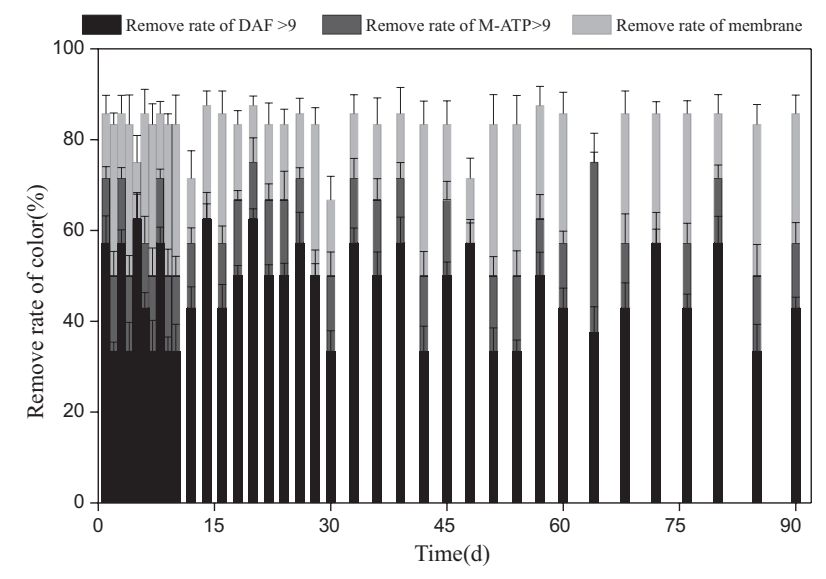

Fig. 5. Comparison of color removal rate of different processing units.

The color of the membrane effluent was basically stable at 5 in the end of the experiment. The color removal rate of the above three processing units was in order: DAF $>$ membrane $>$ M-ATP.

\section{Odor Removal in Three Units}

The average odor thresholds of raw water and final effluent were 62.30 and 6.22 respectively (Fig. 6), followed the total average removal rate of odor was $90.0 \%$. The average odor value of DAF effluent, M-ATP effluent and membrane effluent were 47.97, 16.89 and 6.22 respectively, and the average removal rate was $23.0 \%, 49.8 \%$ and $17.2 \%$ respectively (Fig. 7 ). In the late stage of the experiment, the membrane effluent odor was basically stable at 5. In summary, the odor removal rate of the above three processing units was in order: $\mathrm{M}-\mathrm{ATP}>\mathrm{DAF}>$ membrane.

\section{Membrane Pollution Assessment}

During the three-month continuous exeriment, the pressure vacuometer values of the membrane device were relatively stable. The TMP value fluctuated

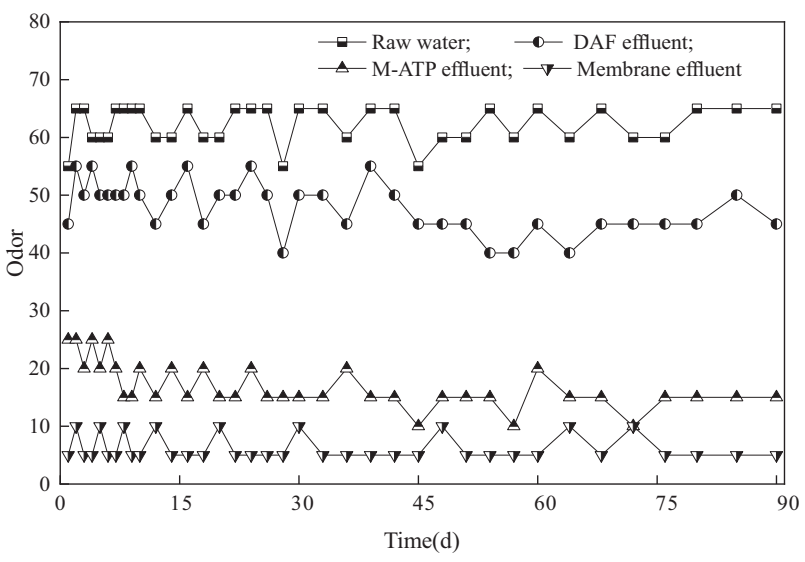

Fig. 6. Odor removal by the integrated process.

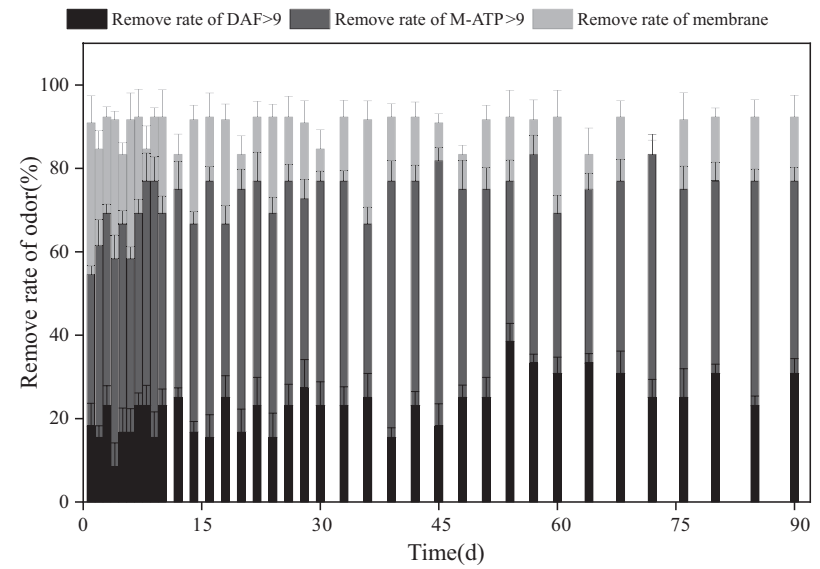

Fig. 7. Comparison of odor removal rate of different processing units.

slightly at the beginning of the experiment, but basically remained at about $2.3 \mathrm{kPa}$ at $10 \mathrm{~d}$. At the end of the experiment, the TMP value was about $4.5 \mathrm{kPa}$, which indicated that the membrane fouling of the process system could be kept at a low level. And this integrated system ran well during the whole experiment.

\section{Discussion}

\section{Processing Ability of DAF unit}

The raw water forms flocs after adding flocculant. In view of the water quality of lake water, such flocs have relatively large volume and loose shape, so it is difficult to achieve natural precipitation especially at the condition of low temperature and low turbidity [25]. The DAF process mainly utilizes the copolymerization and collision adhesion of microbubbles and floc particles, as well as the netting, wrapping and bridging effects of the flocs themselves to achieve the removal of floc particle pollutants [26-27]. This process has also achieved good practical applications in water plants in Jinan city, Zhuhai city and other places [28]. 
a)

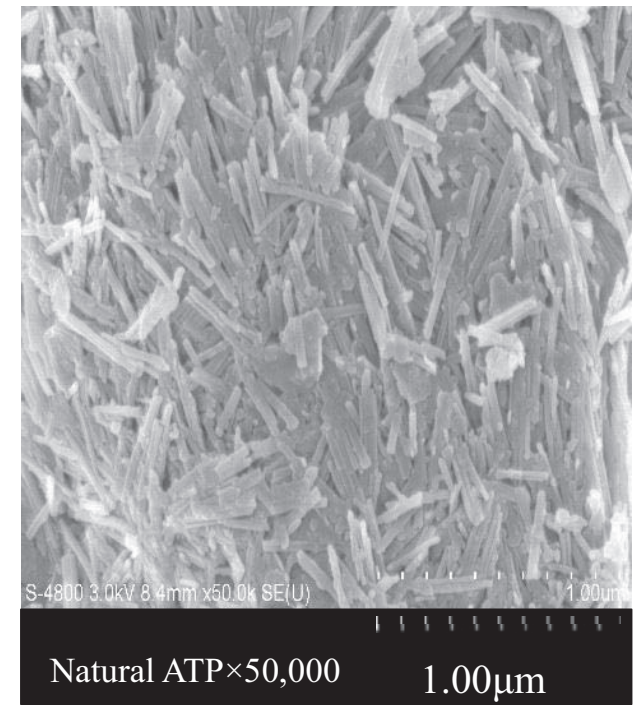

b)

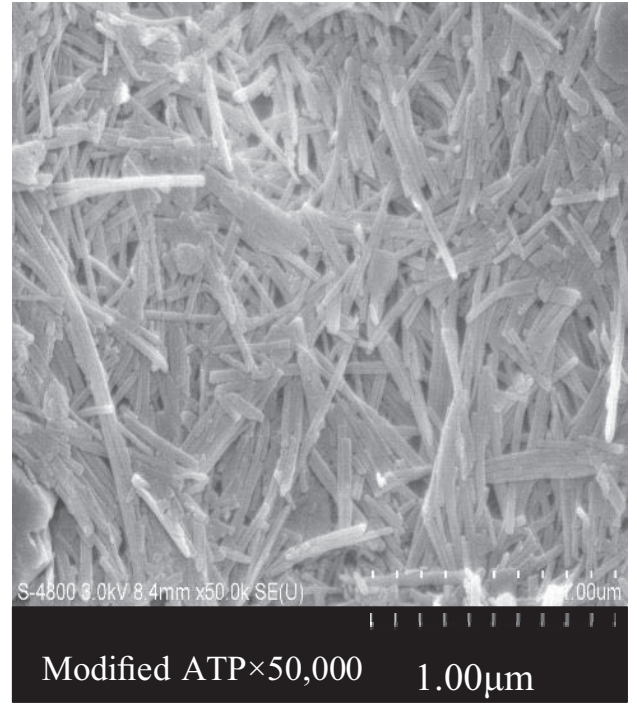

Fig. 8. Scanning electron micrographs of natural attapulgite and modified attapulgite: a) Natural ATP, b) Modified ATP.

DAF process has a significant effect on the treatment of pollutants such as turbidity, color, odor, permanganate index and algae in the water [29-30]. It was found that the performance of microbubbles and the hydraulic retention time have an important effect on the removal of color in the experiment. When hydraulic retention time in M-ATP was $1.5 \mathrm{~h}$, the effect of DAF separation was the best. The DAF processing unit could achieve the best results when the separation time was $1.5 \mathrm{~h}$. Therefore, the effect of DAF on color removal was best, with a removal rate of $46.6 \%$. DAF has the second highest removal rate of turbidity and odor. Chlorine, 2-MIB and Geosmin which could produce odor would attach to the flocs during flocculation process [31].

\section{Processing Ability of M-ATP Unit}

Natural ATP and M-ATP are different aggregates formed by mutual aggregation of crystal bundles (including rod-like crystals). It could be seen from Figure. 8 that modification did not cause the crystal bundles collapse or deform after acid activation. Moreover, more pores were found which meant the increasing specific surface area. The reasons for the increased specific surface area after acid activation are listed below. Firstly, the majority tetrahedron and minority octahedron dissolved from ATP during the process of acidification with sulfuric acid, which account for the increased number of holes in attapulgite. Secondly, acid modification could remove the impurity such as carbonate in the ATP pores, making pores clear and wide. Thirdly, the $\mathrm{H}^{+}$could replace part of ion such as $\mathrm{Na}^{+}, \mathrm{Ca}^{2+}$ and $\mathrm{Mg}^{2+}$ in ATP interlayer via ion exchange because of the smaller radius [32-33].

Modification of natural ATP not only have more specific surface area and pore volume, but also showed the characteristics of good biological affinity. M-ATP provided vast surface area for microorganisms to attach and grow [34]. After the device system was in stable condition, the surface of M-ATP gradually covered with biofilm [24]. Biofilm could absorb suspended solids and colloidal substances in water. They also showed a good treatment effect on sensory indicators such as turbidity, color and odor in water. On the other hand, the particle size of M-ATP was 20-60 mesh, whose function was similar to quartz sand filtration. From this point of view, there is a synergistic relationship between M-ATP and Therefore, while the biofilm on the carrier is acting, M-ATP is also playing the role of filtering and interception, further removing pollutants such as turbidity, color and odor. In this study, the contribution of M-ATP for turbidity and odor removal ranked first. The variations of odor and taste from our research were basically consistent with previous research conclusions. And the turbidity removal rate was slightly different from previous studies due to the difference in the gradation of M-ATP particles [35-36].

\section{Processing Ability of Membrane Filtration Unit}

Membrane filtration process intercepts pollutants via sieving effect [37]. Theoretically, particles with a diameter smaller than $0.2 \mu \mathrm{m}$ can be retained and removed by the microfiltration membrane [38]. Therefore, a pollutants such as turbidity, color and odor could be reduced through membrane filtration. And the quality of the effluent kept stable.

Due to the pre-treatment of DAF process and M-ATP units, the pollutant load of the effluent was relatively low when it entered the membrane filtration process. Therefore, compared with the first two processing units, the removal rate of the three sensory indicators by membrane filtration process was relatively low. Bulk pollutants such as suspended solids, colloids, organic matter, and algae were almost non-existent. Therefore, there was low pollution load for membrane 
filtration process and the system was in stable condition during the experiment. At the end of the experiment, the color of membrane effluent was stable at about 5, with an average value of 6.22. The reason may be due to the broken filaments of the microfiltration membrane module and the shedding of the M-ATP surface material [39-40].

Traditional research on the sensory properties of lake water mostly focused on turbidity, this research not only focused on turbidity, but also analyzed the change of color and odor, which had wider coverage in sensory properties. In addition, this combined process could give full play to the advantages of DAF/ M-ATP/ membrane combined process, shortening the traditional tap water treatment process. The combined process not only has a higher removal rate for the sensory properties of lake water, but also has a higher removal rate for other water quality indicators, such as ammonia nitrogen, total phosphorus, permanganate index, et al, which referred to previous studies of research group $[20,41]$.

\section{Correlation Analysis}

In order to reveal the correlation between the removal rates of the three processing units, SPSS software was used for correlation analysis. Pearson Correlation Coefficient was selected to represent the correlation coefficient. A two-tail test was chosen for significance test. The correlation between three types of sensory indicators, DAF, M-ATP and membrane removal rate was listed in Table 4 . In addition to the general relationship of odor removal rate between DAF and membrane process (-0.373), among the three types of sensory indicators, the DAF process was closely related to the other two process units and the correlation was significant. The DAF removal rate of turbidity had the highest correlation with the membrane removal rate $(-0.658)$. In addition, for turbidity and color removal, the correlation coefficient between M-ATP and membrane removal rate was low $(-0.137,-0.170)$, indicating that the correlation was general.

\section{Conclusions}

In summary, the present study showed the removing effect of DAF, M-ATP and membrane filtration on turbidity, color and odor of micro-polluted lake water. Further, the correlation between those three processing units was discussed.

(1) The DAF/M-ATP/membrane treatment system has a good removal effect on the sensory properties of micro-polluted lake water. The average removal rates for turbidity, color and odor were $95.8 \%, 83.1 \%$ and $90.0 \%$, respectively.

(2) For the removal of turbidity and odor, the contribution degree of the removal rate of the three processing units is in order: $\mathrm{M}-\mathrm{ATP}>\mathrm{DAF}>$ membrane; the contribution degree of the removal rate of color is in order: $\mathrm{DAF}>$ membrane $>$ M-ATP.

(3) The membrane fouling of this combined process is relatively low. The TMP at the beginning and the end of the test are $2.3 \mathrm{kPa}$ and $4.5 \mathrm{kPa}$, respectively, and the operating device is operating well.

\section{Acknowledgments}

This work was supported by the National Natural Science Foundation of China (51978001), the Natural Science Foundation of Anhui Province (1808085ME133; KJ2020A0365), and the Natural Science Foundation of Anhui Polytechnic University (KZ42020243).

\section{Conflict of Interest}

The authors declare no conflict of interest.

\section{References}

1. SAMEH S.A., REKHA B., HASIM K., HASSAN I.M., SUNIL K.S. Improved water resource management framework for water sustainability and security. Environmental Research, 201, 111527, 2021.

2. MAZHAR A., MUHAMMAD A., SYED E., BUSHRA M., MUHAMMAD Y., ABDUL G., GHULAM A.S, ASIF T., MUNAWAR I. Vibrio fischeri bioluminescence inhibition assay for ecotoxicity assessment: A review. Science of The Total Environment, 626, 1295, 2018.

3. MUNAWAR I. Vicia faba bioassay for environmental toxicity monitoring: A review. Chemosphere, 144, 785, 2016.

4. ZHANG Q., YANG Y.Q., CHEN F.R., ZHANG L.L., RUAN J.J., WU S.J., ZHU R.L. Effects of hydraulic loading rate and substrate on ammonium removal in tidal flow constructed wetlands treating black and odorous water bodies. Bioresource Technology, 321, 124468, 2021.

5. Ecological Environment Bulletin revised of China. Available online: http:// www.mee.gov.cn /hjzl/sthjzk/ zghjzkgb/202006/P020200602509464172096.pdf (accessed on 06-07-2020).

6. XIAO Y., RIISE G. Coupling between increased lake color and iron in boreal lakes. Science of The Total Environment, 767, 145104, 2021.

7. YANG P., YANG C., YIN H. Dynamics of phosphorus composition in suspended particulate matter from a turbid eutrophic shallow lake (Lake Chaohu, China): Implications for phosphorus cycling and management. Science of The Total Environment, 741, 140203, 2020.

8. ZHANG R., QI F., LIU C., ZHANG Y., WANG Y., SONG Z., KUMIRSKA J., SUN D. Cyanobacteria derived taste and odor characteristics in various lakes in China: Songhua Lake, Chaohu Lake and Taihu Lake. Ecotoxicology and Environmental Safety, 181, 499, 2019.

9. GUO Q., DING C., XU H., ZHANG X., LI Z., LI X., YANG B., CHEN T., WANG C., YU J. Diagnosing complex odor problems occurring in micro-polluted source water: Primary approach and application. Environmental Pollution, 271, 116373, 2021. 
10. GOUGH R., HOLLIMAN P.J., WILLIS N., FREEMAN C. Dissolved organic carbon and trihalomethane precursor removal at a UK upland water treatment works. Science of The Total Environment, 468, 228, 2014.

11. PHATTHALUNG W.N., SUTTINUN O., PHUNGSAI P., KASUGA I., KURISU F., FURUMAI H., MUSIKAVONG C. Non-target screening of dissolved organic matter in raw water, coagulated water, and chlorinated water by Orbitrap mass spectrometry. Chemosphere, 264, 128437, 2021.

12. LIU J., WU Y., WU C., MUYLAERT, K., VYVERMAN, W., YU, H., MUÑOZ, R., RITTMANN, B. Advanced nutrient removal from surface water by a consortium of attached microalgae and bacteria: A review. Bioresource Technology, 241, 1127, 2017.

13. LIU Z., WEI H., LI A., YANG H. Enhanced coagulation of low-turbidity micro-polluted surface water: Properties and optimization. Journal of Environmental Management, 233, 739, 2019.

14. PAN L., CHAO W., YANG Y.X., WANG Y., YU S.L. Effects of microbubble ozonation on the formation of disinfection by-products in bromide-containing water from Tai Lake. Separation and Purification Technology, 193, 408, 2017.

15. LUAN D., HOFFMANN M T., DANIEL L.A. Coagulation and dissolved air flotation as a harvesting method for microalgae cultivated in wastewater. Journal of Water Process Engineering, 32 (C), 100947, 2019.

16. NGUYEN H.V., KIM J.K., CHANG S.W. A case study of low pressure air flotation ferryboat for algae removal in Korean rivers and lakes. Journal of Industrial and Engineering Chemistry, 69, 32, 2019.

17. VINGERHOEDS M.H., NIJENHUIS-DE VRIES M.A., RUEPERT N., VAN DER LAAN H., BREDIE, W.L.P., KREMER, S. Sensory quality of drinking water produced by reverse osmosis membrane filtration followed by remineralisation. Water Research, 94, 42, 2016.

18. YIN H., YANG P., KONG M., LI W. Use of lanthanum/ aluminum co-modified granulated attapulgite clay as a novel phosphorus (P) sorbent to immobilize $\mathrm{P}$ and stabilize surface sediment in shallow eutrophic lakes. Chemical Engineering Journal, 385, 123395, 2020.

19. LIU J., LI B., WANG Y., LI X. Passage and community changes of filterable bacteria during microfiltration of a surface water supply. Environment International, 131, 104998, 2019.

20. ZHAO C.S., XU X.P., RUAN R.J., SUN J.W., CAO J.S., LIU Q. Mechanism Study of Combined Membrane Bioreactor for Micro-Polluted LakeWater Treatment. Technology of Water Treatment, 47 (2), 90, 2021 [In Chinese].

21. DONG L., LIN L., LI Q., HUANG Z., TANG X., WU M., LI C., CAO X.M. Enhanced nitrate-nitrogen removal by modified attapulgite-supported nanoscale zero-valent iron treating simulated groundwater. Journal of Environmental Management, 213, 151, 2018.

22. XIAO Y., ROHRLACK T., RIISE G. Unraveling long-term changes in lake color based on optical properties of lake sediment. Science of The Total Environment, 699, 134388, 2020.

23. XUWEI D., MIN Q., REN R., JIARUI L., XIAOXUE S., PING X., JUN C. The relationships between odors and environmental factors at bloom and non-bloom area in Lake Taihu, China. Chemosphere, 218, 569, 2019.

24. YI X.S., ZHAO Z.W., SHI W.X., DUAN Y.S., SUN N., MA C., XIE Y.Z. Organic pollutants variation and antifouling enhancement with attapulgite clay addition in MBR treating micro-polluted surface water. Chemical Engineering Journal, 223, 891, 2013.

25. LANG P., MEIS S., PROCHÁZKOVÁ L., CARVALHO L., MACKAY E.B., WOODS H.J., POTTIE J., MILNE I., TAYLOR C., MABERLY S.C., SPEARS B.M. Phytoplankton community responses in a shallow lake following lanthanum-bentonite application. Water Research, 97, 55, 2016.

26. OH H.S., KANG, S.H., NAM S., KIM E., HWANG T. CFD modelling of cyclonic-DAF (dissolved air flotation) reactor for algae removal. Engineering Science and Technology, an International Journal, 22, 477, 2019.

27. WANG Y., JIN X., YANG S., WANG G., XU L., JIN P., SHI X., SHI Y. Interactions between flocs and bubbles in the separation zone of dissolved air flotation system. Science of The Total Environment, 761, 143222, 2021.

28. XU K., LI Y., ZOU X., WEN H., SHEN Z., REN X. Investigating microalgae cell-microsphere interactions during microalgae harvesting by ballasted dissolved air flotation through XDLVO theory. Biochemical Engineering Journal, 137, 294, 2018.

29. LEE K.H., KIM H., KUK J.W., CHUNG J.D., PARK S., KWON E.E. Micro-bubble flow simulation of dissolved air flotation process for water treatment using computational fluid dynamics technique. Environmental Pollution, 256, 112050, 2020.

30. FONSECA R.R., THOMPSON J.J.P., FRANCO I.C., DA SILVA F.V. Automation and Control of a Dissolved Air Flotation Pilot Plant. IFAC-PapersOnLine20th IFAC World Congress, 50, 3911, 2017.

31. SHIN J., LEE D., HWANG T., LEE Y. Oxidation kinetics of algal-derived taste and odor compounds during water treatment with ferrate(VI). Chemical Engineering Journal, 334, 1065, 2018.

32. YIN H., HAN M., TANG W. Phosphorus sorption and supply from eutrophic lake sediment amended with thermally-treated calcium-rich attapulgite and a safety evaluation. Chemical Engineering Journal, 285, 671, 2016.

33. DUTT M.A., HANIF M.A., NADEEM F., BHATTI H.N. A review of advances in engineered composite materials popular for wastewater treatment. Journal of Environmental Chemical Engineering, 8, 104073, 2020.

34. SHI W.X., DUAN Y.S., YI X.S., WANG S., SUN N., MA C. Biological removal of nitrogen by a membrane bioreactor-attapulgite clay system in treating polluted water. Desalination, 317, 41, 2013.

35. ZHAO C.S., HU Y., LIU Q., XUE Z.X. Integrated Process of Flotation, Modified Attapulgite and Membrane for Treatment of Micro-polluted Surface Water. Water Saving Irrigation, 9, 47, 2018 [In Chinese].

36. LIU Q., YAN M., ZHAO C.S., ZHAO T.X. Integrated Process of Flotation, Activated Carbon and Membrane for Treatment of Micro-polluted Lake Water. China Water \& Wastewater, 30, 57, 2014 [In Chinese].

37. ZHANG Y., FU Q. Algal fouling of microfiltration and ultrafiltration membranes and control strategies: A review. Separation and Purification Technology, 203, 193, 2018.

38. SZYMAŃSKI D., ZIELIŃSKA M., DUNALSKA J.A. Microfiltration and ultrafiltration for treatment of lake water during algal blooms. Ecohydrology \& Hydrobiology, 19, 351, 2019.

39. YIN H., YAN X., GU X. Evaluation of thermally-modified calcium-rich attapulgite as a low-cost substrate for rapid 
phosphorus removal in constructed wetlands. Water Research, 115, 329, 2017.

40. DAS B., CHAKRABARTY B., BARKAKATI P. Preparation and Characterization of novel Ceramic Membranes for Micro-filtration Applications. Ceramics International, 42, 14326, 2016.
41. ABDULLAH A.H., FORTUNATO L., ZAOURI N., GHAFFOUR N., LEIKNES T.O. Role of dissolved air flotation (DAF) and liquid ferrate on mitigation of algal organic matter (AOM) during algal bloom events in RO desalination. Separation and Purification Technology, 256, 117795, 2021. 
